\title{
NARRATIVITY AND THE PATTERNING OF EXPERIENCE: READING HEMINGWAY AS PART OF THE POPULAR CULTURE
}

\begin{abstract}
The narrative form requires a capacity of structuring and patterning both the language and the experience: its objective is the attribution of meaning and articulation of experience. Reading is a process which produces its own fictional truths by prioritizing a coherent historical focus rather than the puzzling elements of the identity which cannot be observed, analyzed or reconstructed. According to Teresa de Lauretis, "the history proper, in the modern definition, achieves both narrativity and historicality by filling in the gaps left in the annals and by endowing events with a plot structure and an order of meaning" (de Lauretis, 1984, pp. 127-8). In the mythical-textual mechanics, the protagonist is predetermined to be of male gender, whereas his chief interest and main obstacle must be female (de Lauretis, 1984, p. 119). This practice turns out to be universal, and we can observe it in many fields: in arts and in popular culture alike, in epics, stories, novels and non-fiction as much as in TV shows which put male figures at the centre. The mythical subject is typically male, "he is the active principle of culture, the establisher of distinction, the creator of differences", unlike the female who is not "susceptible to transformation, to life or death" but rather a mere "element of plot-space, a topos, a resistance, a matrix and matter" (de Lauretis, 1984, p. 119). The paper will focus on some narrative strategies and cultural practices Hemingway's fiction is working with.
\end{abstract}

KEYWORDS: Hemingway, narrative, popular culture, Oedipal hero.

1 vladislava.gordic.petkovic@ff.uns.ac.rs 
In his groundbreaking essay "The Storyteller" (1936), Walter Benjamin mourns the inevitable loss of oral storytelling and the craft it demanded, mostly because it implicated, among other things, the disappearance of the storyteller's living immediacy. Owing to the expansion of written fictional narratives such as novels or short stories, the living figure of the storyteller and the art of oral storytelling fade into oblivion. Modern society, Benjamin lamented, had "abbreviated storytelling" (Fernandes, 2018). In the era of social networks, the stories and their plots have become an easily digestible and accessible sound bites on one's news feed or timeline, increasing popularity as its complexity decreased: "If modern society abbreviated storytelling, the digital era has eviscerated it" (Fernandes, 2018). Fernandes suggests that "we should heed Benjamin's call for more deeply contextualized and complex storytelling - the slow piling of thin, transparent layers, one on top of the other - so much needed in today's world" (Fernandes, 2018). Storytelling might not invite magic, but it is a highly necessary practice of quotidian revelation, needed to disclose the essence of things.

The notion of a more complex and therefore more revelatory storytelling invites the idea of a text that would contain more semantic substance than can be observed at first sight. Pervasive and protean in many aspects, the minimalist narrative is perhaps one of the most intriguing literary text types and models of narrative strategies that can be detected in American fiction, immediately recognizable owing to its deliberate vagueness which can be both bleak and playful, or to the glimpses of profundity than can be found in trivial communication only. In the cultural context of the 1970's in America, the minimalist narrative came to be a mixture of empathy and irony, very close to a communicative model or recurring pattern of white upper-middle-class single-trait characters who wrestle with loneliness and anxiety. However, the most prominent forerunner of minimalism as such is an author who cared less for societal issues and much more for the timeless essence of masculine struggle for maturity: that was Ernest Hemingway, with his insatiable narrative urge as well as his terse and oblique style which was based on the art of delicate reduction. His hero constructed as male and white usually embodies the active principle and becomes a part of a textual mechanics that insists on producing masculine heroes while marginalizing women characters. Hemingway did not care much about popular culture, although he could never be qualified as a writer for elites either. Nevertheless, he 
embraced the demanding task of conveying complex ideas through simple images that is characteristic of popular culture. Hemingway's male world is relatively simple, often tacit and static, even comparable to today's paradigms of character types found in mass culture products, but ready to open up to sharp observation. The underlying message of popular culture projects is never what it seems to be; as is mostly the case with contemporary cult figures and cult phenomena, there is always a hidden agenda, especially with the feminist issues which seem to be the most contested and the easiest to dispute. In some of Hemingway's stories there is not much to say or to happen, but the changes within the protagonists can be immense.

The easiest way to explain why certain books survive over time and maintain their place in the literary canon is to refer to their being part of a "cultural conversation" (Comley and Scholes, 1994, p. ix). The best known of Hemingway's books that became a part of popular culture, The Old Man and the Sea, turns out to be one of his works which is generally the most misunderstood. Its reputation has changed in time but it has remained an incontestable part of contemporary male narratives picturing a lonesome hero who is both desperate and dignified in his deep and humble respect for the selected code of values. Hemingway's last major work kicked off as a popular product, as the Life magazine published the full version of The Old Man and the Sea in its first September issue in the year 1952. Some 5,3 million copies were sold in the next two days. The Old Man and the Sea became an instant attraction, grasping huge readership, and it remained on the best-seller list for six months. Scribner's sold the first printing of 50,000 copies, and the Book of the Month Club chose the Santiago narrative as a main selection with a first printing of 153,000 copies. It needed not more than a year to see The Old Man and the Sea translated into nine foreign languages and published worldwide. The book came at the very end of Hemingway's publishing career and although its sense of defeat contradicted the writer's powerful public image, it was loved by the readers who valued Santiago's quiet strength and perseverance. Very quickly, The Old Man and the Sea started being taught in the USA middle schools and high schools, and it became a very popular read outside the classroom as well.

Hemingway's critics and biographers cannot be said to have received The Old Man and the Sea with accolade; most of them did not succumb to the public adoration of the book and the expected 
praise and admiration were replaced by harsh criticism. Jeffrey Meyers is one of those critics who points out at some weaknesses of the narrative he considers "radical", such as "sentimentality," "self-pity," and "forced and obtrusive" Christian symbolism (Cain, 2006, p. 112). "In the highly acclaimed old Man and the Sea," Meyers states, "Hemingway either deceived himself about the profundity of his art or expressed his contempt for Life, Scribner's, the reading public, the critics, and religion by writing an ironic and mock-serious fable that gave them exactly what they wanted and expected" (Cain, 2006, p. 112). Kenneth Lynn agrees with Meyers, coming to the same conclusion: "Today, there is only one question worth asking about The old Man. How could a book that lapses repeatedly into lachrymose sentimentality and is relentlessly pseudo-Biblical, that mixes cute talk about baseball... with crucifixion symbolism of the most appalling crudity... have evoked such a storm of applause from highbrows and middlebrows alike - and in such overwhelming numbers?" (Cain, 2006, p. 112). The mystery of the popular success and the possible irony of it remain shrouded till today.

Nowadays, more than six decades after its first publication and despite its strong message of male indurance, The Old Man and the Sea seems to occupy only a minor position in Hemingway studies. The reason for this lack of academic interest might be found in its obvious insensitivity towards sexuality and gender issues, the dominant topics which obsessed most Hemingway scholars during the last thirty years. Hence this short narrative of masculine heroism and endurance has been mentioned in passing, ignored and almost forgotten by the critics who have chosen a broader focus on gender or cultural topics. Still, the presence of provocative masculinity issues has not always meant that the work would attract critical attention. One of Hemingway's lesser known stories, a largely neglected one, written in May 1926, entitled "Today is Friday," takes us to biblical times and topics through a seeming uneventfulness that duly follows after a major turmoil in the history of humanity. Hemingway's story records the conversation among three unnamed Roman soldiers late in the night that followed after the day of the crucifixion, revolving around the issues of suffering, pain, endurance, courage and salvation. The second soldier is anxious to know why Jesus did not come down from the cross, and the answer he gets from the first soldier is quite unexpected: the crucified man, according to him, did not want to come down because "that's not his play." The second soldier adamantly refuses to 
accept that explanation, insisting that coming down from the cross is something everybody would do: "Show me one that doesn't want to get down off the cross when the time comes." Although it seems that Hemingway's use of the Christ motif brings a breath of medieval play into the popular culture blindly obsessed with sports, on a deeper level it questions the validity of popular concerns which often spring from cowardice and egoism. Biblical parallels and Christian heritage are used within a specific pattern which invokes idolatry, sacrifice and endurance at the same time. The questionable form and genre, the fact that "Today is Friday" resembles a play or a script much more than a short story, accentuates the meanings of archetypes, valour, integrity and dignity. The story also shows how strongly Hemingway's narrative is influenced by art and painting: first of all, the narrative is remarkably static and the visual effects are focused on invoking pain and violence which are not narrated but rather surrounded with silence.

We know that Hemingway was captivated by representations of Jesus on the cross and pondered them often. The image figures, for example, in many paintings by the old Masters he revered and examined in the Louvre, the Prado, and other museums. "Lots of nail holes," says Frederic Henry about Andrea Mantegna in A Farewell to Arms, alluding to Mantegna's "The Lamentation over the Dead Christ" (c. 1490), a painting in the Brera National Art Gallery in Milan, where in the summer and fall of 1918 the nineteen-year-old Hemingway recovered from the wounds he described in his letter to his parents. He was haunted by bodies pierced, lacerated, and cut, in anguish like the body of the crucified Jesus. (Cain, 2006, p. 122)

"Today is Friday" prefers dialogue to description because the effaced narrator prioritizes extrospective narrative, deciding not to dwell on the inner turmoil of his protagonists. In terms of style, The old Man and the Sea could not be seen as Hemingway's attempt to relive his style of the 1920s: "In The Old Man and the Sea Hemingway is oriented critically toward his style: he reflects on its strengths and limitations and even exposes its absurdity - the arbitrariness, and yet the necessity, of choosing this word rather than that one for a sentence, and indeed the larger issue of being a writer at all" (Cain, 2006 , p. 114). It seems important to cast Santiago as brave and fanatic, ridiculous and self-aware at the same time. This patient and persevere hero is a true case of grace under pressure, committed to his mission and ready to sacrifice all of his strength and energy to achieve the goal. This consistency is important in popular culture 
which would never opt for a hero that has been torn by divergent forces or lost in contemplation. As most of popular myths, the story of Santiago's temptation and revelation is supposed to encompass all the magnificence and futility of human struggle. Whether Santiago serves as an analogy for the writer himself or any artist who strives to achieve the impossible, is highly debatable, as there is nothing sentimental or sublime about his mission. The fishing is just a simple symbol of a constant risky effort involved in everyday living. "Hemingway wrote against death; he professed that his best sentences could embody a feeling forever even as he knew that this forever could never be forever. A great book is a postponement of the inevitable: there is no defense against Time's scythe. If you think that something will last forever, you are not looking far enough ahead. It is punitive to think in such terms, which is why Hemingway often claimed that his work might win an eternal life after all. It was pretty to think so" (Cain, 2006, p. 117).

The Old Man and the Sea is "a theater of cruelty with a flesh-piercing array of images and terms that complicate the novel's renderings of nature's wonder and humankind's courage" (Cain, 2006, p. 120). The narrative might be read as an existentialist novel, but while the works by Jean-Paul Sartre and Albert Camus (who are considered the most influential existential philosophers) could serve as "contrast and comparison," they are actually not exceptionally important to the investigation of the human soul that Hemingway undertook: his life experience helped him articulate the questions of existence, death and the intermittent struggle all by himself, naturally and logically, and he started contemplating about them while in his young age. Hemingway modeled his style according to the influences from writers such as Sherwood Anderson, Gertrude Stein, James Joyce or Ezra Pound even as he developed his own visions of instincts, maturity, security and life choices, "even as he developed his conceptions of identity and nature within the contexts of his family, his hometown of Oak Park, Illinois, with its schools and churches, his summers in Michigan, and his experiences in love and war" (Cain, 2006, p. 120)

Ernest Hemingway's In Our Time (1925) is a powerful and compelling coming-of-age narrative that has been classified as a set of interconnected short stories or even a novel loosely composed, since the narrative pattern of the book disclosed a preestablished design that related to the universal models of existence on the one hand and Hemingway's strictly personal resolutions and revela- 
tions on the other. Hemingway's sequence of stories dealing with an unassuming American boy who is born and raised in the Midwest alternates more or less developed fictional narratives with much shorter and less articulate patches of text which enable brief glimpses into startling images of suffering, mutilation, death, panic and pain. This kind of dual patterning of one's experience inspired several critics such as Michael Reynolds, Edmund Wilson, and Peter A. Smith to comment extensively on the genre of the book, in agreement about its strategic function of mediating the otherwise unspeakable acts and moods. According to Edmund Wilson, the pattern of In Our Time includes a number of more or less traditional stories, each of them introduced by "brief and brutal sketches of police shootings [...] and incidents of the war" (Wilson, 1947, p. 215). D. H. Lawrence suggested that In Our Time is a "fragmentary novel" or "a series of sketches from a man's life" (Lawrence, 1947, p. 644). The kernel of the genre dilemma lies in the narrativity itself, as it is constantly transformed from heroic to mundane, thus providing a widely recognizable pattern which affected the readers as strange and annoying but also as familiar and plausible. The question of the genre classification is far surpassed by the critical urge to define a narrative center in Hemingway's fiction which would regularly be male, white, self-assured, strong and virile. The widening gyre of genre demonstrates that the narrative center in Hemingway's fiction is rather a masculine hero than the narrative itself, so that Nick Adams emerges as the glue which miraculously manages to hold the changeable and fluid text together.

There are clear parallels of In Our Time with Sherwood Anderson's collection of stories Winesburg, Ohio, but the central character of the latter book, a young and aspiring writer who witnesses the painful loneliness of his fellow citizens, is reduced to an observer with a gift to describe ordinary things in a minimalist, but still poetical manner. Anderson's George Willard is the central intelligence and main force that does not allow the individual stories to disperse, and also the narrative centre which gathers random fictional texts into a consistent testimony of solitude, but his active participation in the theatre of life and death is extremely limited if compared to the Hemingway's hero's scope of experience. Regardless of the traumatic load he is given, Nick Adams turns out to be a reflector, not an omniscient narrator who controls the plot, and it is only towards the end of the book, in passing, that he is referred to as a writer. While we know of George Willard's life and opinions 
only what the stories of other characters allow us to see, Hemingway's focus rests exclusively on Nick, and we read about the unspoken conflicts with his mother, the disturbing pedagogy of his father, his early love affairs and his first fears of commitment, his encounters with the strange geometry of dying, the ways he copes with either the horrors of the battlefield or failed peacetime expectations, while his early attempts at writing literature remain hidden, as if they were shameful and irrelevant, or the chunks of a future narrative which is in the process of becoming consistent.

The prevailing sense of shock and loss in In Our Time, as well as its underpinning atmosphere of fear, shock and disgust, triggers the same questions the reader of James Joyce's Dubliners and Sherwood Anderson's Winesburg, Ohio may ask. Although the continual presence of George Willard transforms a set of more or less accidental stories into an intimate and poignant history of a small American town, Winesburg, Ohio has a central character as a cohesive force. Anderson's book demonstrates how a town can influence attitudes and dreams of a young man and it possesses the unity of place and action willfully neglected in Hemingway's book. The ways In Our Time has been read for decades could be described as attempts at establishing a heroic quest narrative, although Hemingway's text questions the urge to establish a heroic center and subjects the idea to reconsideration. There might have been many other strategies offered by the text itself that could propel interpretation, but class, gender and culture had always been relegated to the periphery of Hemingway's artistic concerns.

The privileged narrator aside, the strategies of formal experiment found in James Joyce's Dubliners and Sherwood Anderson's Winesburg, Ohio were by no means radical as those Hemingway applied in his first collection of stories. In Our Time is structured as a bunch of stories about the childhood and youth of an American Everyman, interspersed with fragments classified as "chapters" or "interchapters," mostly dealing with the scenes both from the First World War, and the peacetime incidents of terror and violence captured in a seemingly reticent and covert, but otherwise remarkable and memorable idiom. As they paradoxically focus on fear, horror and death which they are, strangely enough, visibly disinclined to develop, describe and discuss, the chapters gradually but persistently introduce darker and more pessimistic tonalities into the volume: "the varied voices of the interchapters, with their experimental use of dialogue, vernacular and satirical elements provide 
strong images of death and horror that further fragment the work into increasingly volatile units" (Tetlow, 1992, p. 99). However, the reviewer most preoccupied with the generic form of In Our Time was a writer basically disinterested in issues of functional narrative, D. H. Lawrence, not Hemingway's at that time not very wide readership. The very title In Our Time suggests the firm connection between fictitious events and real life, between the past and the present, but at the same time insists on the difference between what is reported as fact and what is not simply derived but actually invented from the real experience. The so called Adams stories which constitute an important part of In Our Time report about various temptations and revelations of Nick's early years, young age and growing up, and thus D. H. Lawrence may be the first to understand that they lay a foundation for a disrupted and irregular Bildungsroman, a specific type of novel which deals with growing up amid exciting and strange events which shape up one's character but also come along with a myriad of moods and feelings difficult both to communicate to others and explain to oneself.

Hemingway's deliberate and carefully designed crudeness of idiom might be indebted to his experience in journalism which taught him how to evoke memorable scenes rather than describe them. Hemingway relied on formal devices preferred by cinematic narration such as juxtaposition, instead of verbosity. The strategy of juxtaposing stories and chapters became an insightful idea about how to set a pattern focused on "private, individual experience depicted in the stories against glimpses of the largely anonymous life of the public world perceived in the vignettes" (Gordić Petković, 2015. p. 154). Thus the form and the function are related more closely than we tend to think: "What became known as the Hemingway code - honourable behaviour in situations of physical or other danger, fair play, courage and dignity in defeat - was exemplified above all in his short stories, the brevity and intensity of which provided a formal analogy to the brief but intense periods of time in battle or sport" (Gordić Petković, 2015. p. 154). There were only few predecessors who might have demonstrated the efficient strategies of showing more by telling less, but Hemingway obviously knew how to handle the challenge.

The main challenge seems to be the image of masculinity that needed to be framed into a carefully constructed, yet crude and unsettling narrative. That is why the narrative theories elaborated by Teresa de Lauretis in Alice Doesn't: Feminism, Semiotics, Cinema 
"help us reconsider the heroic quest narrative, the role of the phallocentric hero, and the ways we read Hemingway as a creator of traditional models of masculinity" (Gordić Petković, 2014, p. 244). Her approach values the Hemingway hero as a binding narrative force, proving to be helpful only if the departure from the manhood conceived by traditional representations of masculinity becomes visible. To build a character that would support a masculine, Oedipal narrative demands much time and energy; it turns into a painful process which demands a sharp focus on the previously established narrative centre: "The connection between the narrative and the Oedipus, desire and narrative [...] urges a reconsideration of narrative structure - or better, narrativity" (de Lauretis, 1984, pp. 104-105). Narrativity is introduced as one of the most intricate elements in the realm of literature: "According to de Lauretis, the object of narrative theory is not narrative, but narrativity: not the structure of narrative, but its work and the effects it produces. Focused on processes of textual and semiotic production, she wishes to reexamine the relations of narrative to genres, on the one hand, and to epistemological framework on the other" (Gordić Petković, 2014, p. 244). De Lauretis evaluates the form and function of narrative in forms of artistic representation which include epic, myth, fiction and film, in firm conviction that, as we produce hierarchical value structures in narratives, we engender narratives as well. Responding to Sigmund Freud's idea that the Oedipal conflict provides an answer to gender identification, de Lauretis implies that most of common reading practices actually fail to recognize diverse subject perspectives and those narrative desires that spring from sources other than the central hero: supporting characters, villains and other figures that actually help anticipations and conflicts to develop are not allowed to have perspective of their own, and the reader is denied the knowledge about what the sidekicks, or the love interest of the protagonist see or feel. Everyone except the hero on the quest is a mere function, a formal constituent of the plot, whereas the hero is supposed to embody the apparently contradicting values of individuality and companionship.

"The heroic quest narrative is the one that follows the hero through the sequence of events that contribute to his self-recognition, enabling the reader to witness the process of rising conflict and climax which defines male sexuality, and according to de Lauretis, produces the masculine or Oedipal narrative" (Gordić Petković, 2014, p. 245). By contrast, the anti-Oedipal narrative openly 
decides not to focus on a central hero and opens to reading based upon the various locations and sources of narrative desire in the text. In the mythical-textual mechanics, according to de Lauretis, the hero must be male, because his obstacle, whatever its personification, must be female (de Lauretis, 1984, p. 119). This system seems to be working universally in arts and popular culture alike, in epic poems, novels and creative non-fiction as much as in TV shows with male characters at the centre. The mythical subject is constructed as male, "he is the active principle of culture, the establisher of distinction, the creator of differences," whereas female is not "susceptible to transformation, to life or death; she (it) is an element of plot-space, a topos, a resistance, a matrix and matter" (de Lauretis, 1984, p. 119).

The misconception of Hemingway's hero, who is battered and frail, much more a "bitter parody of manhood" than "a paragon of socially constructed masculine authority" (Gordić Petković, 2014, p. 240), becomes obvious only with the growing awareness that his short stories narrate about the encounter with a frightening and eerie universe which is both scary and unconquerable, impossible to understand, handle and control, with the chaotic and fragmentary nature of experience and consequently with the hero who is disoriented, alienated and confused. A typical Hemingway's protagonist is sharply focused on the present moment, instinctively understanding that this strategy would be the only way to keep his sanity. The details might confuse and mislead him, but the overall pattern remains understandable as long as there is at least a remote trace of a higher design above the quotidian turmoil. Such a strange paradox of experience related to human condition can be appropriately rendered only in the short story, but it is also seized by the popular culture: "The prevailing mood of disenchantment, confusion and bitterness seems to go along perfectly with the artistic form of short story, which requires the focus on the turning point in the character's life and chooses to dwell on a particular moment of crisis, climax or change" (Gordić Petković, 2014, p. 240). Far from being obsessed with grand style and majestic sentences, Hemingway is carefully working with linguistic economy, whose small but definite effects bring his writing closer to popular culture which demands a quick pace and ready-made interpretations. Those minimalist maneuvers successfully depict a hero whose life is far from any ordinary daily routine but still understandable and appealing. The telegraphic language camouflages the silent disap- 
pointment of the hero whose closely inspected masculinity surpasses the temptations of short-lived, irrelevant experiences in favour of obeying higher principles of courage and integrity, so that the much supported paradigm of the Oedipal hero engenders the impression that the author such as Hemingway must be looking for a verified narrative authority and an authoritative presence to relate the authentic grandeur of the so called Hemingway hero.

Hemingway's minimalistic techniques test the possibilities of art by refusing to follow most of the conventions that were established with the idea to endow realistic narrative with the elements of literary artifice and provide it with transitory effects. Hemingway's art seems to be divided between unattainable literary objectives and a simple, concise and appealing idiom of the print media. Beginning his writing career as a newspaper reporter on The Kansas City Star, Hemingway adopted the 110 rules of the paper's style-sheet that imposed a severe verbal discipline on him, but drew him closer to the reading public. Some of them insisted on simple sentences and concise paragraphs, the others asked for "vigorous English"; there are also rules demanding elimination of superfluous and redundant words, and those calling for brevity, precision, accuracy and clarity as well (Gordić Petković, 2014, p. 240). For example, rule 21 instructed the author to "avoid the use of adjectives, especially such extravagant ones as splendid, gorgeous, grand, magnificent etc" (Gordić Petković, 2014, p. 240). Hemingway obeys this instruction not only in his first collection of stories, but throughout his writing career. In pretty much the same way he converts a common journalist style into a delicate and focused literary idiom, Hemingway alters his real experience to a significant degree, with the intention to transform it into fiction: in his later career of a writer who served as a journalist and war correspondent there were several examples of how he started writing an article or a news dispatch and ended up with a short story instead. While he covered the Spanish Civil War for the North American Newspaper Alliance, Hemingway used the field notes he collected both for writing dispatches and fictional forms. The best example of how the fictional text and a newspaper article might be identical in form but divergent in function is found in the story "Old Man at the Bridge", which confronts the impartial and objective standpoint of a foreign correspondent with a dismal perspective of an old man forced to leave his home village and worrying more about the animals left behind than his own safety. 
It is easy to understand why Teresa de Lauretis chooses to discuss Oedipus as the principal hero of the male narrative, since it was Sigmund Freud who "chose the hero of Sophocles' drama as the emblem of Everyman's passage into adult life" (de Lauretis, 1984, p. 125). In her opinion, all narratives closely imitate the logic and structure of the Oedipus's, since they require development both towards solution and the reconstruction of the moment in time when the quest began. Narrative is thus a continual search for understanding in which our awareness of loss plays a substantial part; therefore Oedipus' loss of eyesight also denotes a long journey undertaken to restore his vision. The narrative form requires a capacity of structuring and patterning both language and experience: its objective is the attribution of meaning and articulation of experience. What turns Hemingway's characters into mythical heroes is either "the psychic wounding or trauma" (Comley and Scholes, 1994, p. 8), in spite of the fact that the writer bitterly opposed this reduction of his artistic achievement to a traumatic reflex (Comley and Scholes, 1994, p. 8). The psychic wounds "may indeed shape the concern of artists, what makes them artists instead of mere members of the walking wounded is what they can textualize, what they can draw within the bounds of textuality so that it can be brought to consciousness either by the writer or by the readers" (Comley and Scholes, 1994, p. 8).

The easiest way to explain why certain books survive over time and maintain their place in the literary canon is to refer to their being part of a "cultural conversation" (Comley and Scholes, 1994, p. ix). "They survive because succeeding generations of readers find their concerns represented in those texts and feel a need to discuss them with others, whether in casual speech or in more formal contexts like ours" (Comley and Scholes, 1994, p. ix). The central issue of manliness sheds light on Hemingway's less successful literary representations, such as his fictional women, which are so often inscribed into his text as mere variants of recognizable female types. As Comley and Scholes suggested a quarter-century ago, the Hemingway who was taught about in high school is dead. The new Hemingway emerges, the one who left his machismo behind the bars of numerous frameworks he had been persistently caught in: that is a new Hemingway who is here to stay for quite some time. The Hemingway studies will continue to deal with a Hemingway constantly pursued by the thrill of creation as well as the remembrance of death. The concepts of creation and death 
seem to be strangely mixed into the popular culture, which misses the writer of In Our Time and The Old Man and the Sea more than ever.

REFERENCES Benjamin, W. (2006). The Storyteller: Reflections on the Works of Nikolai Leskov. In: Hale, D (ed.). The Novel: An Anthology of Criticism and Theory 1900-2000. (362-378). Malden, Mass: Blackwell Publishing.

Cain, W. E. (2006). Death Sentences: Rereading The Old Man and the Sea. Sewanee Review, Winter 2006, 114 (1), 112-125.

Comley, N. R. and R. Scholes. (1994). Hemingway's Genders: Rereading the Hemingway Text. New Haven and London: Yale University Press.

De Lauretis, T. (1984). Alice Doesn't: Feminism, Semiotics, Cinema. Bloomington: Indiana University Press.

Fernandes, S. (2018). The Evisceration of Storytelling. Retrieved from: https://blog.oup.com/2018/06/curated-stories-storytelling/

Gordić Petković, V. (2014). Blurring or Expanding the Boundaries of Genre? The Narrative Centre of Hemingway's In Our Time. In: Zorica Đergović-Joksimović, Sabina Halupka-Rešetar (eds.), English Studies Today: Prospects and Perspectives, (237-246). Novi Sad: Faculty of Philosophy.

Gordić Petković, V. (2015). Realism in the Contemporary American Short Story. Nasleđe, 32, 151-161.

Hemingway, E. 1986. In Our Time. New York: Macmillan.

Lawrence, D.H. (1947). Review of In Our Time. In: Diana Trilling (ed.), The Portable D. H. Lawrence (644-648). New York: Penguin.

Tetlow, W. E. (1992). Hemingway's In Our Time: Lyrical Dimensions. London and Toronto: Bucknell University Press.

Wilson, E. (1947). Hemingway: Gauge of Morale. In: The Wound and the Bow, (214-243). New York: Oxford University Press.

ВЛАДИСЛАВА С. ГОРДИЋ ПЕТКОВИЋ

УНИВЕРЗИТЕТ У НОВОМ САДУ

ФИЛОЗОФСКИ ФАКУЛТЕТ

ОДСЕК ЗА АНГЛИСТИКУ

РЕЗИМЕ

ПРИПОВЕДАЬЕ КАО ФОРМИРАЮЕ ИСКУСТВА:

ХЕМИНГВЕЈ У ПОПУЛАРНОЈ КУЛТУРИ

Наративизација је процес који подразумева формирање искуства у кохерентну целину која у виду забележеног сведочанства о свету одражава захтеве и приоритете културе у којој настаје. 
Један од културних императива очитује се у потреби да се образује едиповски јунак у складу с маскулиним обележјима снаге и одлучности, снажан и непоколебљив, спреман да превазиђе препреке али истовремено обузет и егзистенцијалним и моралним питањима и дилемама.

На примеру Хемингвејеве прве збирке прича У наше време и новеле Cйарац и море, која је његово последње остварење али истовремено и дело које је оживело пишчеву популарност и веома ठрзо постало део читалачке културе и школске лектире подједнако, покушаћемо да представимо обликовање стваралачке поетике овог аутора, њену укорењеност у искуство, литерарне узоре и савремену уметност, као и да препознамо степен уклапања Хемингвејевог опуса у популарну културу и дефинишемо кључне одреднице које их повезују.

КључнЕ РЕчи: Хемингвеј; нарација; популарна култура; едиповски јунак.

Овај чланак је објављен и дистрибуира се под лиценцом Creative Commons Ауторство-Некомерцијално Међународна 4.0 (СC BY-NC 4.0 |

https://creativecommons.org/licenses/by-nc/4.0/).

This paper is published and distributed under the terms and conditions of the Creative Commons Attribution-NonCommercial International 4.0 licence (CC BY-NC 4.0 | https://creativecommons.org/licenses/by-nc/4.0/). 